International Review of Research in Open and Distributed Learning

Volume 20, Number 2

April - 2019

\title{
Systematic Mapping Study of Academic Engagement in MOOC
}

Brenda Edith Guajardo-Leal, Claudia Navarro-Corona, and Jaime Ricardo Valenzuela González

Tecnologico de Monterrey

\begin{abstract}
MOOCs are presented as an affordable and easily accessible modality that offers the opportunity to democratize education in our time; however, this convenience training favors a low completion rate of the participants. Faced with this situation, scholars have suggested that it is necessary to deepen the construct of academic engagement, a concept that has been addressed in the study of face-to-face training, to better understand how students participate in this educational modality. This article systematically explores the existing literature, in the period of 2015-2018, about the construct of academic engagement in online, massive and open learning courses, through a Systematic Mapping of Literature, a method which aims to identify the characteristics of production in a given subject. The results show that there is a considerable increase in published articles that associate academic engagement and MOOCs, mainly from the United States, Australia, and the United Kingdom. Most of the mapped publications employ qualitative methods, with an exploratory approach, although there are several correlational studies. The study of participation patterns and instructional design appear as the main topics of interest in the field. In addition to providing a general overview of production on the subject, the research provides accurate information that will identify works for more in-depth reviews. Thus, it also offers a replicable and flexible literature search method for different research interests.
\end{abstract}

Keywords: MOOC, academic engagement, e-learning, technology 


\section{Introduction}

Talking about massive, open and online courses (MOOCs) means referring to a low-cost educational offering, with the possibility of connection at any time and place. Although the idea of education at convenience is accessible to the user, it also encourages participants to postpone, forget, or disengage from carrying out the academic activities (Kizilcec, Piech, \& Schneider, 2013; Milligan, Littlejohn, \& Margaryan, 2013). Academic research records show that although a large number of students enroll to start MOOCs, only a small fraction manages to complete them (Halawa, Greene, \& Mitchell, 2014; Jordan, 2014). Therefore, there is consistent criticism among MOOCs researchers, one of which is that this method does not offer students the necessary structures to learn significantly and autonomously, which causes lack of persistence, lack of motivation and, finally, course desertion (Conole, 2015; J ordan, 2014; Milligan et al., 2013).

The possibility offered by MOOCs to democratize education and the limitation of its low completion rate have led to an area of interest for educational research. Although some authors consider that research in MOOCs is an incipient and challenging area (de Barba, Kennedy, \& Ainley, 2016; Gašević, Dawson, \& Siemens, 2015; Greene, Oswald, \& Pomerantz, 2015), since their emergence in 2006 research has focused on (1) studying aspects to motivate participants to complete the courses (e.g., Kizilcec, Pérez-Sanagustín, \& Maldonado, 2016; Kizilcec \& Schneider, 2015); (2) identifying aspects related to self-regulation of learning to reduce dropout or predict performance and/ or retention (e.g., Kizilcec et al., 2016); and, (3) analyzing course design elements for the same purpose (e.g., Conole, 2015). These three topics are linked to what other researchers have called academic engagement in the classroom modality.

Researchers have studied the academic engagement construct as a way to improve discontent, avoid boredom, improve motivation and student participation in academic activities, increase success levels, and understand the positive development of students (Appleton, Christenson, \&Furlong, 2008; Carter, Reschly, Lovelace, Appleton, \& Thompson, 2012; de Barba et al., 2016; Valdivia, Ramírez-Montoya, \& Valenzuela, 2018). Academic engagement is also studied as being a valuable construction to capture the gradual process by which students abandon academic activities (Appleton et al., 2008; Kizilcec et al., 2013). In MOOCs, researchers and educators consider academic engagement as the main theoretical foundation to intervene and understand possible dropouts, to improve positive performance, and encourage the completion of an educational goal (J oksimovic et al., 2018).

As every cognitive construct, there is no single definition or form of measurement for engagement. Newmann, Wehlage, and Lamborn (1992) define it as the psychological inversion in which the student invests energy and effort to understand something. Meanwhile, York, Gibson, and Rankin (2015) indicate that engagement is a term generally used to refer to the student's psychological investment, his or her willingness to invest time in educational behaviors, or to a general reference of student involvement in educational activities. In MOOCs, engagement can be conceptualized in a similar way as in face-to-face education; however, its operationalization, in terms of the forms and processes of data collection, is totally different. According to Joksimović et al. (2018), in MOOCs, engagement consists of time spent on course activities, participation in tests and exams, time spent in videos, and participation in exercises and assignments. 
Given the emerging condition of academic engagement as a construct associated with MOOCs as a response to the problem of low success found in these educational environments, this research aims to map the scientific production on academic engagement in MOOCs published in the years 2015, 2016, 2017 and in the beginning of 2018, to identify the specific lines of study within this topic. The research answers the question: What has been the production in the three-year period between 2015 and 2018 on academic engagement in MOOCs?

Studies on the academic engagement of participants in MOOCs are recent; however, the subject is in consolidation as a line of study, and several literature reviews associated with the construct have been done. Different authors have identified academic engagement as a research trend in MOOCs. Ebben and Murphy (2014), for example, analyzed 25 articles published between 2011 and 2013 with the objective of identifying research topics on MOOCs. The following trends stand out in their results: academic engagement, creativity, learning analytics, evaluation, and critical discourses. Subsequently, Sa'Don, Alias, and Ohshima (2014), examined 164 articles published between 2008 and 2014 with the same objective as Ebben and Murphy, specifically in institutions of Higher Education. Their results highlight research trends such as evaluation and engagement/motivation, social interaction, retention, politics, instructional design, and cultural diversity. Authors like Anderson, Huttenlocher, Kleinberg, and Leskovec (2014) and Kizilcec, Pérez-Sanagustín, and Maldonado (2016) argue that there is still little understanding of how students participate and become involved in MOOCs, and that this construct is still under construction.

Bozkurt, Akgün-Özbek, and Zawacki-Richter (2017) conducted a systematic literature review that identified trends and research patterns in massive environments. The authors reviewed 362 empirical articles from 2008 to 2015 and conducted content and discourse analyses. Among their results they found that: (1) research on MOOCs would increase in subsequent years; (2) conceptual/ descriptive studies are the most used methodology in MOOCs, constituting the majority of articles (53.3\%) in almost all years studied; (3) the three main areas of research in MOOCs are: theories and models, characteristics of the students, and instructional design; and (4) the second most used methodology is quantitative research (19.6\%) with few surveys, correlational, or experimental studies.

Raffaghelli, Cucchiara, and Persico (2015) discussed the methodological approaches in MOOCs research between 2008 and 2014. Their analysis covered 60 articles, and the results of their study show that the majority of the research consisted of theoretical studies and case studies, and, like Bozkurt et al. (2017), the authors found that experimental studies are very scarce. In their discussion, Raffaghelli, Cucchiara, and Persico (2015) emphasize that the theoretical frameworks to address research questions in the area are not clear and that there is little interest in knowing about the tools and methodological aspects of MOOCs research.

Veletsianos and Shepherdson (2016) analyzed the published empirical literatures on MOOCs between 2013 and 2015 and from 2013 to 2015. In their results they show that: (1) more than 80\% of the literature in the area was published in North America and Europe; (2) almost half of the works lacked citations; (3) a quantitative focus was favored for carrying out research in MOOCs through surveys and automated methods; (4) qualitative methods, which are a minority in their study, use interviews, observations, and focus groups; and (5) little research is done about the instructor or expert (Veletsianos \& Shepherdson, 2016). 
Joksimovic et al. (2018) conducted a literature review on learning approaches in MOOCs. In their study, they analyzed the constructs related to the learning used in the prediction and measurement of the engagement and the learning outcome (J oksimovic et al., 2018). One of the results reported by the authors was the lack of solid frameworks to explain learning in an open online environment, thus they proposed an appropriate framework for open online contexts based on the model as developed by Reschly and Christenson (2012), which defines engagement as a process and as a result (J oksimovic et al., 2018).

The analysis of the reviews allows us to deduce that, although the conclusions of the research have suggested that academic engagement is a relevant construct to understand the participation of students in MOOCs, researchers on this environment have not incorporated the concept in their literature reviews. Thus, as pointed out by Anderson et al. (2014) and Kizilcec et al. (2016), the understanding of how students participate is still scarce.

\section{Method}

The research was developed through a Systematic Mapping Study (SMS). SMS is a type of literature review used to identify, select, and synthesize production in a specific field or associated with a concept, with the purpose of identifying what evidence is available on the subject (Cooper, 2016; Kitchenham \& Charters, 2007). As outlined by Kitchenham and Charters (2007), a SMS focuses on classification, thematic analysis, and identification of publication without evaluating quality. This type of study differs from systematic reviews, which focus on quality, in order to identify the best practices based on empirical evidence (Kitchenham \& Charters, 2007).

According to the authors reviewed (Cooper, 2016; Dybå, Dingsøyr, \& Hanssen, 2007; Kitchenham \& Charters, 2007; Petersen, Vakkalanka, \& Kuzniarz, 2015), the method of the present work was structured in three central moments: (1) the search approach, (2) the search protocol, and (3) the analysis. Each one is described below.

\section{First Moment: Search Approach}

The approach consisted in the formulation of the following questions to guide the inquiry:

1. How many studies are in the range of 2015 to March 2018?

2. In which country were the works published in the period indicated?

3. Who are the authors of the most cited documents?

4. What documents are referenced most frequently?

5. What journals/ conferences have been interested in the production of the academic engagement construct? 
6. What methodological perspectives, designs, and approaches to educational research are most used in the study of the construct?

7. What type of instruments are most used in the study of academic engagement in MOOCs participants?

8. What thematic lines emerge in the study of academic engagement in MOOCs participants?

\section{Second Moment: Development of the Search Protocol}

The search protocol was designed based on the steps performed by Petersen, Vakkalanka, and Kuzniarz (2015) both for the selection of scientific production and for its analysis. Figure 1 graphically represents this process.

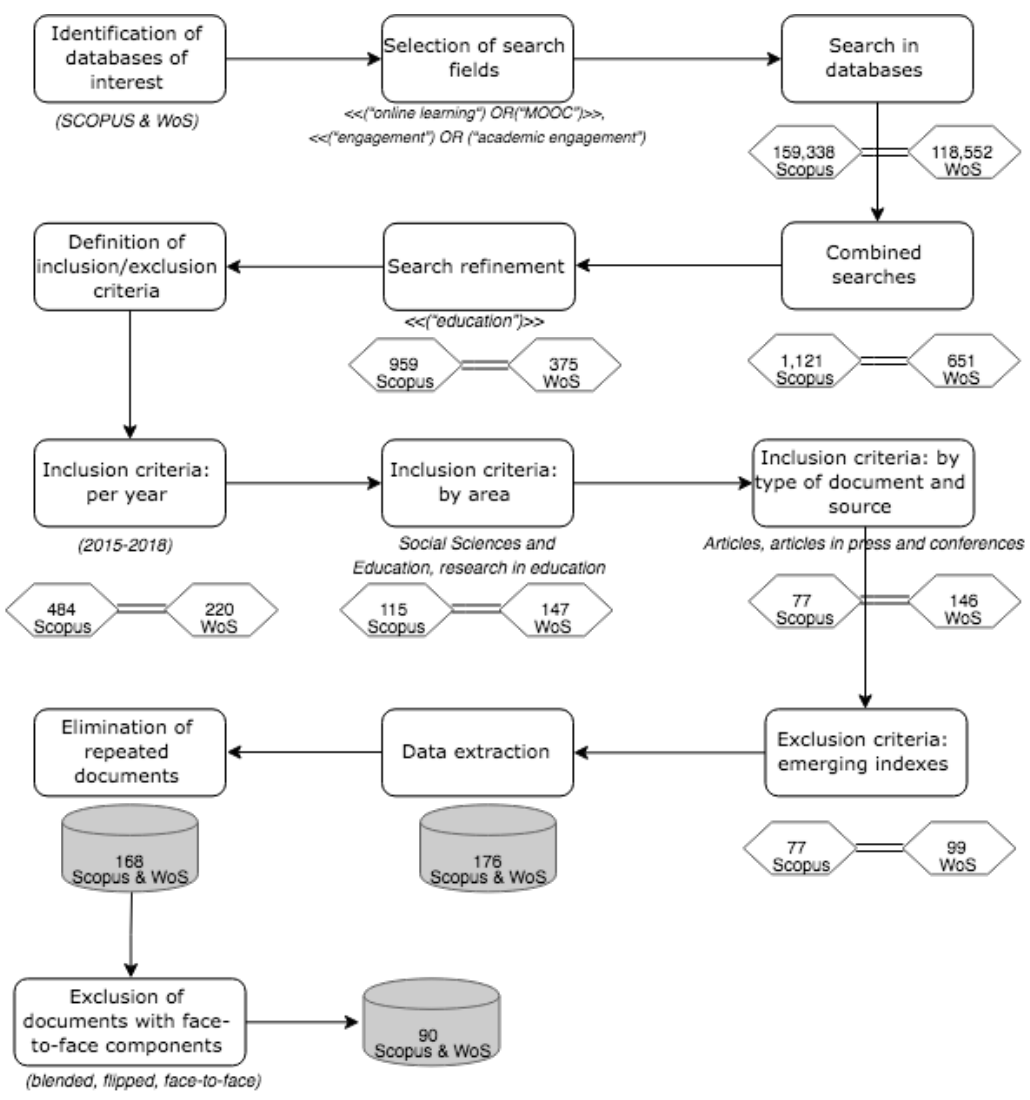

Figure 1. Flow diagram of the search protocol.

As recommended by Dybå, Dingsøyr, and Hanssen (2007), indexes were chosen that met different quality criteria: (1) containing intelligent tools to track, analyze and visualize the research; (2) integrating global critical and scientific research; and (3) having peer evaluation. The two databases chosen that met the quality criteria mentioned were: (1) Scopus and (2) Web of Science (WoS). This allowed a global search of production in fields such as science, technology, medicine, social sciences, and arts and humanities. 
Searches in Scopus and WoS were carried out on March 1st, 2018. To have control over the search result for analysis after this work, several individual search expressions were created. Once the individual searches were carried out, a combination of searches was done. Table 1 shows the individual and combined searches, and the results obtained in each step.

Table 1

Boolean Expressions and their Combination in Scopus and WoS

\begin{tabular}{lrc}
\hline \multicolumn{1}{c}{ Boolean expression } & SCOPUS & WoS \\
\hline$(<<$ online learning $>>)$ OR $(<<$ MOOCs $>>)$ & 18,075 & 11,226 \\
$(<<$ engagement $>>)$ OR $(<<$ academic engagement $>>)$ & 141,263 & 107,326 \\
Combined search $(<<$ onlinelearning $>>)$ OR $(<<$ MOOCs $>>)$ & 1,121 & 651 \\
AND $(<<$ engagement>>) OR (<<academic engagement $>>)$ & 959 & 375 \\
$(<<$ education $>>)$ & & \\
\hline
\end{tabular}

Note. The search was conducted on March 1st, 2018.

Four inclusion criteria were defined: (1) per year (2015-2018), (2) per area (the one with the highest frequency), (3) per type of document and source (articles, articles in press and conferences), and (4) per language (English). One exclusion criterion was set: without emerging indexes. Regarding the fourth inclusion criterion (per language), it is important to mention that no documents were found in a language other than English, so it was not considered as part of the flow diagram of the search protocol. The results for each index are shown in Table 2. 
Table 2

Inclusion and Exclusion Criteria Results in Scopus and WoS

\begin{tabular}{|c|c|c|c|c|}
\hline \multirow[b]{2}{*}{$\begin{array}{c}\text { Inclusion / exclusion } \\
\text { criteria }\end{array}$} & \multicolumn{2}{|c|}{ SCOPUS } & \multicolumn{2}{|c|}{ WoS } \\
\hline & Selection & Results & Selection & Results \\
\hline Per year & $2015-2018$ & 484 & $2015-2018$ & 220 \\
\hline Per area & Social sciences & 115 & $\begin{array}{l}\text { Education and } \\
\text { educational } \\
\text { research }\end{array}$ & 147 \\
\hline $\begin{array}{l}\text { Per type of document } \\
\text { and source }\end{array}$ & $\begin{array}{l}\text { Articles, articles } \\
\text { in press and } \\
\text { conferences }\end{array}$ & 77 & $\begin{array}{l}\text { Articles, articles } \\
\text { in press and } \\
\text { conferences }\end{array}$ & 146 \\
\hline Per language & English & 77 & English & 146 \\
\hline $\begin{array}{l}\text { Without emerging } \\
\text { indexes }\end{array}$ & $\begin{array}{l}\text { Only established } \\
\text { indexes }\end{array}$ & 77 & $\begin{array}{l}\text { Only established } \\
\text { indexes }\end{array}$ & 99 \\
\hline
\end{tabular}

In summary, 77 documents from the Scopus database and 99 documents from the WoS database were considered, a total of 176 documents to continue with the extraction, analysis, and classification of results.

\section{Third Moment: Analysis and Classification}

As a part of this step, data extraction was performed. Of the 176 documents chosen (see Figure 1), the following information was extracted from each database: (1) authors, (2) names, (3) abstracts, (4) year of publications, (5) type of sources, (6) number of citations, and (7) type of documents.

In some cases, journals are indexed in both databases, Scopus and WoS. For this reason, the next step was to identify duplicated documents that were found in both databases; eight duplicated documents were deleted and 168 documents were eligible for consideration. Finally, an analysis was made to detect and exclude documents with face-to-face components (blended, flipped classroom). Thus, 78 documents were discarded, and a total of 90 documents were considered in the investigation (see Figure 1 to consult the analysis and classification procedure).

The 90 documents selected were then grouped into the three main research perspectives: quantitative, qualitative, or mixed methods. To address other questions of the present investigation, the classification scheme of educational research designs provided by Creswell (2007, 2012), and Creswell and Poth (2018) was used, in addition to Hurtado's (2010) research approach classification. Figure 2 shows the different alternatives for perspectives, designs, and approaches sought in the review. 


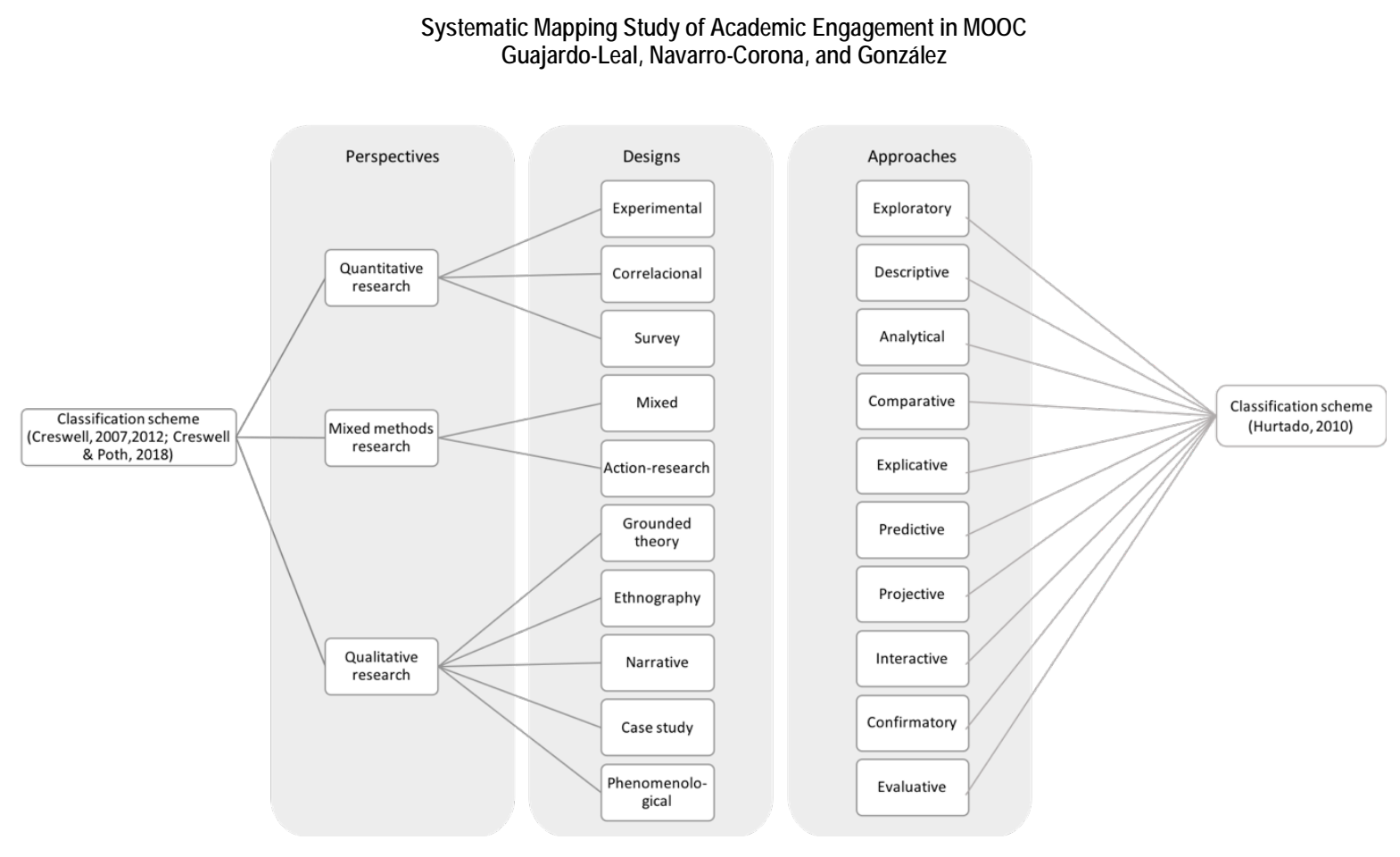

Figure 2. Perspectives, designs, and approaches sought in educational research.

On the other hand, the specific thematic lines were identified in an emergent way from reading, coding, and classifying the thematic contents of the abstracts of the selected works. In the following section, the results obtained are presented.

\section{Results}

\section{How Many Studies are in the Range of 2015 to March 2018?}

The final count of documents admitted with the selected criteria was 90 (see mapped production at https://goo.gl/yvViRV), 44 from Scopus and 46 from WoS. The summary of the documents selected by database and by year can be found in Figure 3, which shows an increase of the research carried out in both databases from 2015 to 2017. 


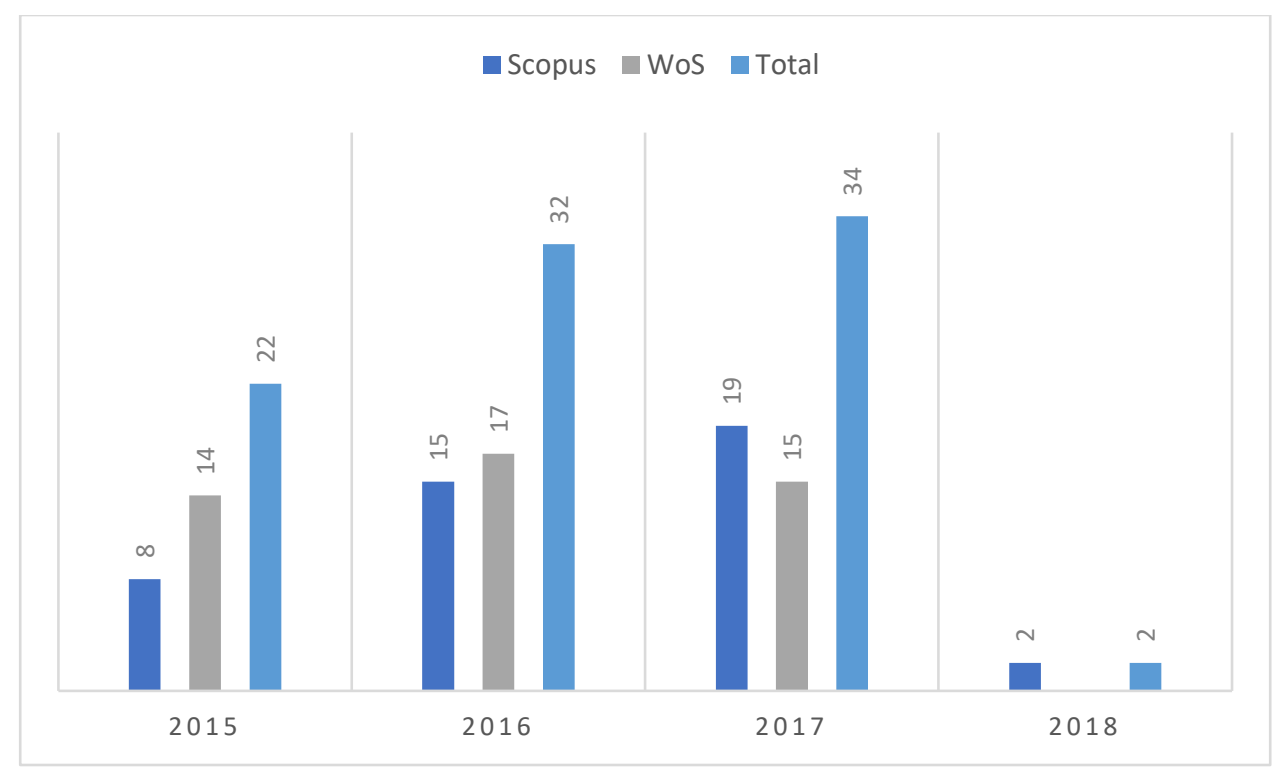

Figure 3. Documents selected by database and by year.

From 2015 to March 2018, a greater number of articles were published (78\%) than conferences (22\%). The difference is greater in 2017, where $94 \%$ of the documents are articles and only $6 \%$ are conferences. Table 3 shows the sets of articles according to their type and year of publication.

Table 3

Documents Selected by Type

\begin{tabular}{|c|c|c|c|c|}
\hline Year & Articles & Conferences & Article identifier & Conference identifier \\
\hline 2015 & $64 \%$ & $36 \%$ & $\begin{array}{l}{[A 35, \text { A36, A37, A38, A39, A40, }} \\
\text { A41, A42, A43, A45, A46, A47, A51, } \\
\text { A52] }\end{array}$ & $\begin{array}{l}\text { [A83, A84, A85, A86, A87, } \\
\text { A88, A89, A90] }\end{array}$ \\
\hline 2016 & $69 \%$ & $31 \%$ & $\begin{array}{l}\text { [A19, A20, A21, A22, A23, A24, } \\
\text { A25, A26, A27, A28, A29, A31, A32, } \\
\text { A33, A34, A44, A48, A49, A50, } \\
\text { A56, A71, A72] }\end{array}$ & $\begin{array}{l}\text { [A57, A74, A75, A76, A77, } \\
\text { A78, A79, A80, A81, A82] }\end{array}$ \\
\hline 2017 & $94 \%$ & $6 \%$ & $\begin{array}{l}\text { [A02, A03, A04, A05, A06, A07, } \\
\text { A08, A09, A10, A11, A12, A13, A14, } \\
\text { A15, A16, A17, A18, A30, A53, A54, } \\
\text { A55, A58, A59, A61, A62, A63, A64, } \\
\text { A65, A66, A69, A70, A73] }\end{array}$ & {$[\mathrm{A} 67, \mathrm{~A} 68]$} \\
\hline 2018 & $100 \%$ & $0 \%$ & {$[\mathrm{~A} 01, \mathrm{~A} 60]$} & \\
\hline Total & $78 \%$ & $22 \%$ & 70 articles & 20 conferences \\
\hline
\end{tabular}




\section{In Which Country Were the Works Published in the Period Indicated?}

To know in which countries the research on the academic engagement in MOOCs was published, the places of affiliation of the first authors in the selected documents were identified; the geographical distribution is presented in Figure 4. The results show that the research of the construct is present in the five continents, with the largest number of articles published in the United States of America (21), the United Kingdom (16), and Australia (11).

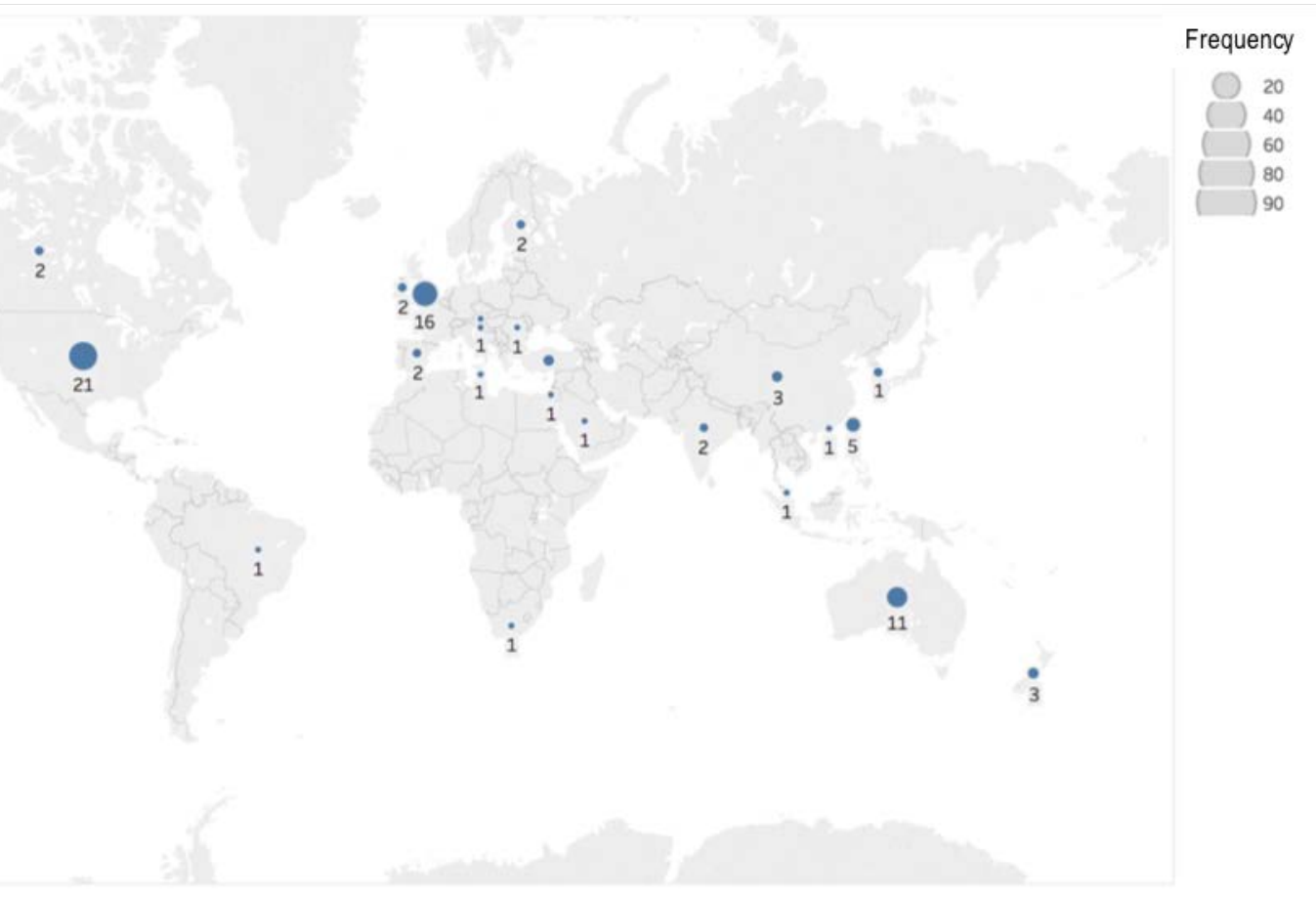

Figure 4. Geographical distribution of documents by frequency.

\section{Who Are the Authors of the Most Cited Documents?}

A total of 9 documents have 11 or more citations reported in the databases, 5 of them from the Scopus database and 4 from WoS. As shown in Table 4, the author with the highest number of reported citations is Jordan, K. with the article: Massive Open Online Course Completion Rates Revised: Assessment, Length and Attrition (26 citations). In second place is Toven-Lindsey, B., Rhoads, R. A., and Lozano, J . B. with the article: Virtually Unlimited Classrooms: Pedagogical Practices in Massive Open Online Courses (24 citations). The third position is from Hew, K. F. with the article: Promoting Engagement in Online Courses: What Strategies can we Learn from Three Highly Rated MOOCs (20 citations). It is important to note that the most cited documents (more than 10 citations) all are articles that were published between 2015 and 2016. The relevance of these articles is relative, since perhaps the documents of the last years (2017 and 2018) did not have enough time to be cited; however, this is a limitation of the methodology (Kitchenham \& Charters, 2007). The results of this exercise are important for the purposes of this research, since the most cited documents of the years 2015 and 2016 are identified. 
Table 4

Most Cited Authors and Documents

\begin{tabular}{|c|c|c|c|c|c|c|}
\hline ID & Authors & Name of the document & Year & $\begin{array}{c}\text { Type of } \\
\text { document }\end{array}$ & Citations & Database \\
\hline A38 & J ordan, K. & $\begin{array}{l}\text { Massive open online } \\
\text { course completion rates } \\
\text { revisited: Assessment, } \\
\text { length and attrition }\end{array}$ & 2015 & $\mathrm{~A}$ & 26 & S \\
\hline A43 & $\begin{array}{l}\text { Toven-Lindsey, } \\
\text { B., Rhoads, R. A. } \\
\text { \&Lozano, J . }\end{array}$ & $\begin{array}{l}\text { Virtually unlimited } \\
\text { classrooms: Pedagogical } \\
\text { practices in massive open } \\
\text { online courses }\end{array}$ & 2015 & A & 24 & $\mathrm{~W}$ \\
\hline A36 & $\begin{array}{l}\text { De Freitas S. I., } \\
\text { Morgan J., \& } \\
\text { Gibson D. }\end{array}$ & $\begin{array}{l}\text { Will MOOC transform } \\
\text { learning and teaching in } \\
\text { Higher Education? } \\
\text { Engagement and course } \\
\text { retention in online } \\
\text { learning provision }\end{array}$ & 2015 & A & 23 & S \\
\hline $\mathrm{A} 24$ & Hew, K. F. & $\begin{array}{l}\text { Promoting engagement } \\
\text { in online courses: What } \\
\text { strategies can we learn } \\
\text { from three highly rated } \\
\text { MOOCs }\end{array}$ & 2016 & $\mathrm{~A}$ & 20 & S \\
\hline $\mathrm{A} 44$ & $\begin{array}{l}\text { Barak, M., } \\
\text { Watted, A., \& } \\
\text { Haick, H. }\end{array}$ & $\begin{array}{l}\text { Motivation to learn in } \\
\text { massive open online } \\
\text { courses: Examining } \\
\text { aspects of language and } \\
\text { social engagement }\end{array}$ & 2016 & A & 19 & W \\
\hline A45 & $\begin{array}{l}\text { Goldberg, L. R., } \\
\text { Bell, E., King, C., } \\
\text { O'Mara, C., } \\
\text { McInerney, F., } \\
\text { Robinson, A., \& } \\
\text { Vickers, J. }\end{array}$ & $\begin{array}{l}\text { Relationship between } \\
\text { participants' level of } \\
\text { education and } \\
\text { engagement in their } \\
\text { completion of the } \\
\text { Understanding Dementia } \\
\text { Massive Open Online } \\
\text { Course }\end{array}$ & 2015 & $\mathrm{~A}$ & 16 & $\mathrm{~W}$ \\
\hline A25 & $\begin{array}{l}\text { Evans, B. J., } \\
\text { Baker, R. B., \& } \\
\text { Dee, T. S. }\end{array}$ & $\begin{array}{l}\text { Persistence patterns in } \\
\text { massive open online } \\
\text { courses (MOOC) }\end{array}$ & 2016 & $\mathrm{~A}$ & 15 & S \\
\hline $\mathrm{A} 40$ & Anders, A. & $\begin{array}{l}\text { Theories and applications } \\
\text { of massive online open } \\
\text { course [MOOC]: The case } \\
\text { for hybrid design }\end{array}$ & 2015 & A & 13 & S \\
\hline
\end{tabular}




$\begin{array}{llllll}\text { Brinton, C. G., } & \text { Individualization for } & 2015 & \text { A } & 11 & \text { W } \\ \text { Rill, R., Ha, S., } & \text { Education at Scale: MIIC } & & & \\ \text { Chiang, M., } & \text { Design and Preliminary } & & & \\ \text { Smith, R., \&J u, } & \text { Evaluation } & & & \\ \text { W. } & & & \end{array}$

Note. $\mathrm{A}=$ Article, $\mathrm{S}=$ Scopus, $\mathrm{W}=$ Web of Science.

In general, 52 documents (58\%) from both databases do not have citations, leaving $42 \%$ of the documents with at least one citation. Of these, $58 \%$ correspond to documents from the WoS database and $42 \%$ to documents from the Scopus database.

\section{What Documents Are Referenced Most Frequently?}

To answer this research question, the references of the 90 selected documents were obtained. Once the database was created, the references that were not in APA format were eliminated, and a total of 2,131 references formed the database to be analyzed. Table 5 shows the references with the highest frequency used for the documents.

Table 5

Most Frequently Referenced Documents

\begin{tabular}{|c|c|c|}
\hline Reference & $\begin{array}{l}\text { Articles that cite } \\
\text { it }\end{array}$ & $\begin{array}{l}\text { Type of } \\
\text { document }\end{array}$ \\
\hline $\begin{array}{l}\text { Kizilcec, R. F., Piech, C., \& Schneider, E. (2013). Deconstructing } \\
\text { disengagement: Analyzing learner subpopulations in massive } \\
\text { open online courses. Third International Conference on Learning } \\
\text { Analytics and Knowledge, LAK'13 Leuven, Belgium. Retrieved } \\
\text { from } \\
\text { https:// web.stanford.edu/ cpiech/ bio/ papers/deconstructingDi } \\
\text { sengagement.pdf }\end{array}$ & $\begin{array}{l}\text { A11, A24, A25, } \\
\text { A28, A38, A45, } \\
\text { A47, A57 }\end{array}$ & Conference \\
\hline $\begin{array}{l}\text { Breslow, L. B., Pritchard, D. E., DeBoer, J ., Stump, G. S., Ho, A. } \\
\text { D., \& Seaton, D. T. (2013). Studying learning in the worldwide } \\
\text { classroom: Research into edX's first MOOC. Research \& Practice } \\
\text { in Assessment, 8, 13-25. Retrieved from } \\
\text { https:// www.rpajournal.com/ dev/ wp- } \\
\text { content/ uploads/2013/05/ SF2.pdf }\end{array}$ & $\begin{array}{l}\text { A24, A38, A44, } \\
\text { A45, A57 }\end{array}$ & Article \\
\hline $\begin{array}{l}\text { Perna, L. W., Ruby, A., Boruch, R. F., Wang, N., Scull, J., Ahmad, } \\
\text { S., \& Evans, C. (2014). Moving through MOOC: Understanding } \\
\text { the progression of users in Massive Open Online Courses. } \\
\text { Educational Researcher, 43, 421-432. } \\
\text { https:// doi.org/ 10.3102/ 0013189X14562423 }\end{array}$ & $\begin{array}{l}\text { A20, A25, A38, } \\
\text { A45, A53, A57 }\end{array}$ & Article \\
\hline $\begin{array}{l}\text { Ho, A. D., Chuang, I., Reich, J., Coleman, C., Whitehill, J ., \& } \\
\text { Northcutt, C. (2015). HarvardX and MITx: Two years of open } \\
\text { online courses (HarvardX Working Paper No. 10). } \\
\text { doi:10.2139/ ssrn.2586847 }\end{array}$ & $\begin{array}{l}\text { A23, A38, A44, } \\
\text { A45, A57 }\end{array}$ & Report \\
\hline
\end{tabular}




\begin{tabular}{|c|c|c|}
\hline Reference & $\begin{array}{l}\text { Articles that cite } \\
\text { it }\end{array}$ & $\begin{array}{l}\text { Type of } \\
\text { document }\end{array}$ \\
\hline $\begin{array}{l}\text { Allen, I.E., \& Seaman, J . (2013). Changing course: ten years of } \\
\text { tracking online education in the United States. Babson Survey } \\
\text { Research Group and Quahog Research Group, Babson Park, MA. } \\
\text { Retrieved from } \\
\text { http:// www.onlinelearningsurvey.com/reports/ changingcourse. } \\
\text { pdf }\end{array}$ & $\begin{array}{l}\text { A07, A18, A21, } \\
\text { A41, A46 }\end{array}$ & Report \\
\hline $\begin{array}{l}\text { J ordan, K. (2014) Initial trends in enrolment and completion of } \\
\text { massive open online courses. The International Review of } \\
\text { Research in Open and Distance Learning, 15(1), 133-160. DOI: } \\
\text { https:// doi.org/ 10.19173/ irrodl.v15i1.1651 }\end{array}$ & $\begin{array}{l}\text { A28, A38, A44, } \\
\text { A45, A46 }\end{array}$ & Article \\
\hline $\begin{array}{l}\text { Conole, G. (2013). MOOC as disruptive technologies: strategies } \\
\text { for enhancing the learner experience and quality of MOOC. } \\
\text { Revista de Educación a Distancia. Número, 39. Retrieved from } \\
\text { http:// www.um.es/ead/red/39/conole.pdf }\end{array}$ & $\begin{array}{l}\text { A12, A24, A28, } \\
\text { A42 }\end{array}$ & Article \\
\hline $\begin{array}{l}\text { DeBoer, J ., Ho, A. D., Stump, G. S., \& Breslow, L. (2014). } \\
\text { Changing “course”: Reconceptualizing educational variables for } \\
\text { massive open online courses. Educational Researcher, 43, 74-84. } \\
\text { https:// doi.org/ 10.3102/ 0013189X14523038 }\end{array}$ & $\begin{array}{l}\text { A25, A38, A45, } \\
\text { A57 }\end{array}$ & Article \\
\hline $\begin{array}{l}\text { Ferguson, R., \&Clow, D. (2015) Examining engagement: } \\
\text { Analyzing learner subpopulations in massive open online courses } \\
\text { (MOOC). In 5th International Learning Analytics and } \\
\text { Knowledge Conference (LAK15; p. 1-8). Poughkeepsie, NY, USA: } \\
\text { ACM. https:// doi.org/ 10.1145/ 2723576.2723606 }\end{array}$ & $\begin{array}{l}\text { A11, A38, A44, } \\
\text { A45 }\end{array}$ & Conference \\
\hline
\end{tabular}

The most referenced documents focus on three major research areas: (1) to describe the development and characteristics of learning environments (e.g., Conole, 2013), (2) to understand how learning is achieved in these environments (e.g., Breslow et al., 2013; Perna et al., 2014), and (3) to understand how to support and motivate participants to continue or complete the courses (e.g., Kizilcec, Piech, \& Schneider, 2013; Jordan, 2014). This result makes sense as recent studies report that the theoretical and empirical frameworks in MOOCs environments are in development (J oksimovic et al., 2018).

\section{What Journals/Conferences Have Been Interested in the Production of the Academic Engagement Construct?}

Research regarding the construct of academic engagement was most frequently published in Elsevier's Computers \& Education (Q1 and h-index of 125), Blackwell Publishing's British J ournal of Educational Technology (Q1 and h-index of 71), Carfax Publishing's Distance Education (Q1 and h-index of 33), and Athabasca University's International Review of Research in Open and Distance Learning (open access, Q1 and h-index of 46). The first three journals listed above are from the United Kingdom and the last from Canada. In terms of conferences, research regarding the construct of academic engagement was published most frequently in the International Technology, Education, and Development (INTED) and the International Conference on Education and New Learning Technologies (EDULEARN), both organized in Spain. Research on this construct also appeared (less frequently) in the journal IEEE Transactions on 
Learning Technologies (Q1 and h-index of 33) and in the J ournal of Computing in Higher Education, both from the United States of America, as well as in the journal Higher Education Research \& Development (Q1 and h-index of 29) from the United Kingdom.

As shown in Table 6, the journals in which research on the construct of academic engagement is published most frequently are in the Quartile 1 with the highest level of impact, also, their h-indexes are greater than 24. This indicates the quality and quantity with which the scientific works of the researchers in the area are being published.

Table 6

Frequencies by Type of Document and Source

\begin{tabular}{|c|c|c|c|c|c|c|}
\hline Type & Source & Country & Impact & h-index & Freq. & ID \\
\hline Journal & Computers \& Education & $\begin{array}{l}\text { United } \\
\text { Kingdom }\end{array}$ & Q1 & 125 & 7 & $\begin{array}{l}\text { A44, A48, A50, } \\
\text { A53, A60, A61, } \\
\text { A63 }\end{array}$ \\
\hline Conference & $\begin{array}{l}\text { INTED 2015, 2016, } 2017: \\
9^{\text {th }} 10^{\text {th }} 11^{\text {th }} \text { International } \\
\text { Technology, Education and } \\
\text { Development Conference }\end{array}$ & Spain & $\mathrm{n} / \mathrm{a}$ & $\mathrm{n} / \mathrm{a}$ & 6 & $\begin{array}{l}\text { A68, A74, A78, } \\
\text { A79, A80, A86 }\end{array}$ \\
\hline Journal & $\begin{array}{l}\text { British J ournal of } \\
\text { Educational Technology }\end{array}$ & $\begin{array}{l}\text { United } \\
\text { Kingdom }\end{array}$ & Q1 & 71 & 5 & $\begin{array}{l}\text { A2, A3, A13, A24, } \\
\text { A36 }\end{array}$ \\
\hline J ournal & Distance Education & $\begin{array}{l}\text { United } \\
\text { Kingdom }\end{array}$ & Q1 & 33 & 5 & $\begin{array}{l}\text { A23, A39, A52, } \\
\text { A64, A66 }\end{array}$ \\
\hline J ournal & $\begin{array}{l}\text { International Review of } \\
\text { Research in Open and } \\
\text { Distance Learning }\end{array}$ & Canada & Q1 & 46 & 5 & $\begin{array}{l}\text { A29, A33, A37, } \\
\text { A38, A40 }\end{array}$ \\
\hline Conference & $\begin{array}{l}\text { EDULEARN15 \& 16: } \\
\text { 7th and 8th International } \\
\text { Conference on Education } \\
\text { and New Learning } \\
\text { Technologies }\end{array}$ & Spain & $\mathrm{n} / \mathrm{a}$ & $\mathrm{n} / \mathrm{a}$ & 4 & $\begin{array}{l}\text { A76, A85, A88, } \\
\text { A89 }\end{array}$ \\
\hline J ournal & $\begin{array}{l}\text { IEEE Transactions on } \\
\text { Learning Technologies }\end{array}$ & USA & Q1 & 33 & 4 & $\begin{array}{l}\text { A46, A54, A59, } \\
\text { A71 }\end{array}$ \\
\hline J ournal & $\begin{array}{l}\text { J ournal of Computing in } \\
\text { Higher Education }\end{array}$ & USA & Q1 & 24 & 2 & $\mathrm{~A} 11, \mathrm{~A} 12$ \\
\hline J ournal & $\begin{array}{l}\text { Higher Education } \\
\text { Research \& Development }\end{array}$ & $\begin{array}{l}\text { United } \\
\text { Kingdom }\end{array}$ & Q1 & 29 & 2 & A6, A35 \\
\hline
\end{tabular}

What Methodological Perspectives, Designs, and Approaches to Educational Research Are Most Used in the Study of the Construct? 
Of the studies in the area, $51 \%$ correspond to qualitative research, $38 \%$ to quantitative research, and $10 \%$ to mixed method studies. Figure 5 summarizes the educational research perspectives identified in the documents.

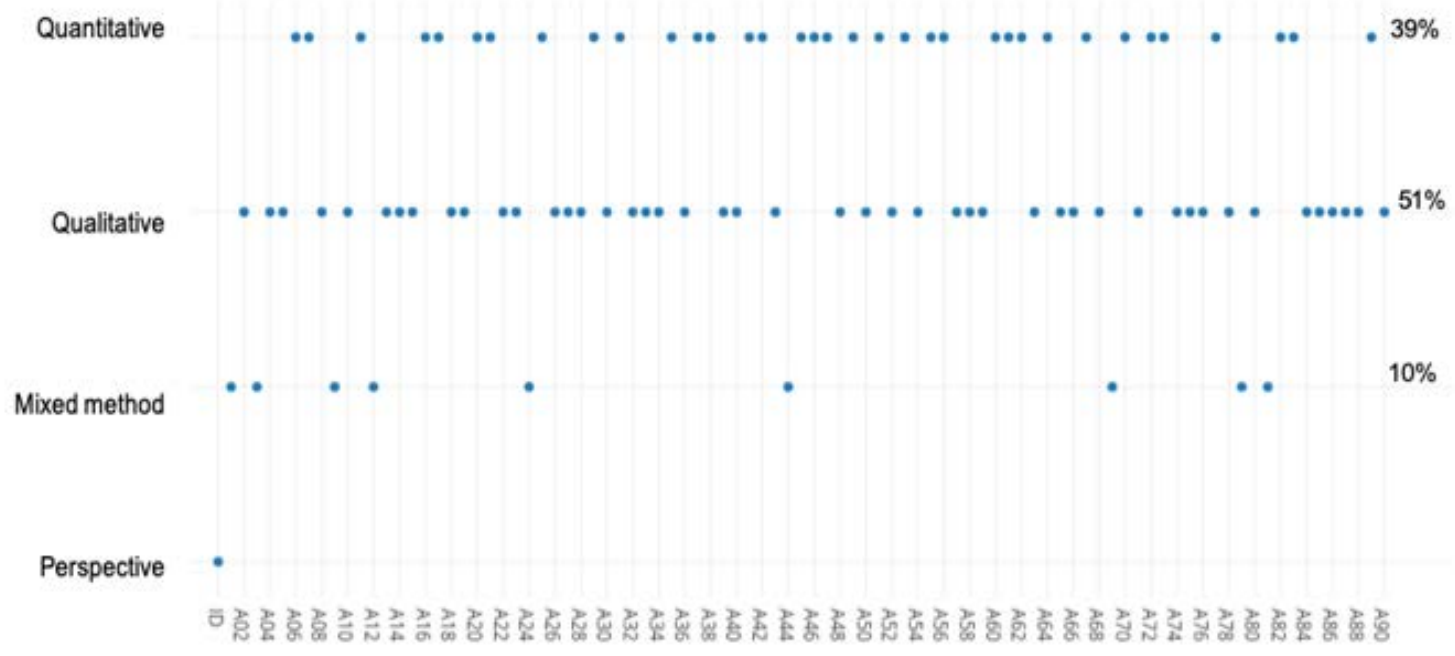

Figure 5. Perspectives of educational research used in documents.

Following the classification scheme of educational research designs provided by Creswell $(2007,2012)$ and Creswell and Poth (2018), it was found that most of the documents correspond to correlation research (31\%), followed by phenomenological research (23\%), case studies (18\%), mixed method studies (9\%), surveys (6\%), and grounded theory (4\%). The least recurrent were the narrative studies (3\%) and the experimental investigations (2\%). In addition to the previous classification, and as the objective of this research, the Systematic Review category is reported with 3\% of production. Figure 6 shows the designs in the mapped production. 


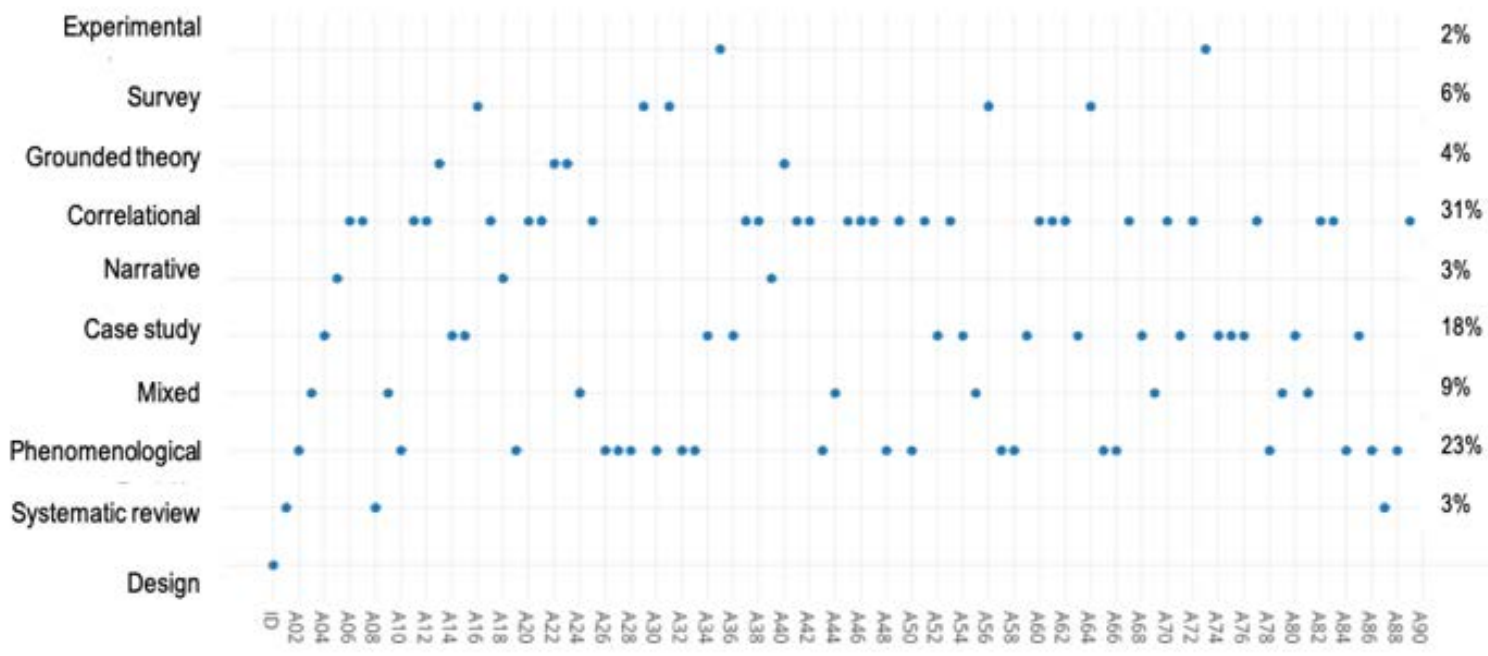

Figure 6. Designs of educational research used in the documents.

Table 7 identifies the sets of documents belonging to each research design. For this analysis it is important to highlight that the titles and abstracts of all documents were read. The method sections of only 36 documents (those that were available in their full-text version), were also read.

Table 7

Classification by Design and Research Method

\begin{tabular}{|c|c|c|c|c|c|}
\hline Design & $\begin{array}{l}\text { Qualitative } \\
\text { research }\end{array}$ & $\begin{array}{l}\text { Quantitative } \\
\text { research }\end{array}$ & $\begin{array}{l}\text { Mixed } \\
\text { methods }\end{array}$ & Total & ID \\
\hline Correlational & & $30 \%$ & $1 \%$ & $31 \%$ & $\begin{array}{l}\text { A06, A07, A11, A12, } \\
\text { A17, A20, A21, A25, } \\
\text { A37, A38, A41, A42, } \\
\text { A45, A46, A47, A49, } \\
\text { A51, A53, A60, A61, } \\
\text { A62, A67, A70, A72, } \\
\text { A77, A82, A83, A89 }\end{array}$ \\
\hline Phenomenological & $23 \%$ & & & $23 \%$ & $\begin{array}{l}\text { A02, A10, A19, A26, } \\
\text { A27, A28, A30, A32, } \\
\text { A33, A43, A48, A50, } \\
\text { A57, A58, A65, A66, } \\
\text { A78, A84, A86, A88, } \\
\text { A90 }\end{array}$ \\
\hline Case study & $18 \%$ & & & $18 \%$ & $\begin{array}{l}\text { A04, A14, A15, A34, } \\
\text { A36, A52, A54, A59, } \\
\text { A63, A68, A71, A74, } \\
\text { A75, A76, A80, A85 }\end{array}$ \\
\hline
\end{tabular}




\begin{tabular}{|c|c|c|c|c|c|}
\hline Mixed & & $1 \%$ & $8 \%$ & $9 \%$ & $\begin{array}{l}\text { A03, A09, A24, A44, } \\
\text { A55, A69, A79, A81 }\end{array}$ \\
\hline Survey & & $6 \%$ & & $6 \%$ & $\begin{array}{l}\text { A16, A29, A31, A56, } \\
\text { A64 }\end{array}$ \\
\hline Grounded theory & $4 \%$ & & & $4 \%$ & $\mathrm{~A} 13, \mathrm{~A} 22, \mathrm{~A} 23, \mathrm{~A} 40$ \\
\hline Narrative & $3 \%$ & & & $3 \%$ & $\mathrm{~A} 05, \mathrm{~A} 18, \mathrm{~A} 39$ \\
\hline Systematic Review & $2 \%$ & & $1 \%$ & $3 \%$ & $\mathrm{~A} 01, \mathrm{~A} 08, \mathrm{~A} 87$ \\
\hline Experimental & & $2 \%$ & & $2 \%$ & A35, A73 \\
\hline
\end{tabular}

An exploratory approach, which seeks to know more about some unknown phenomenon, was found in $32 \%$ of the documents; $23 \%$ of the documents look for explanations of relationships between factors to determine what will be the future behavior or the trend of that event, that is, they follow a predictive approach; $20 \%$ of the documents follow a descriptive approach; in $11 \%$ of the documents, two or more groups are studied and their behavior compared, situating them in the comparative approach; $4 \%$ of the documents follow an evaluative approach; 3\% seek to understand the situations in terms of the relationships of their components following an analytical approach; and 3\% corresponds to confirmatory approaches in which hypotheses are tested. With $2 \%$ and $1 \%$ are the interactive and projective approaches. Figure 7 shows the approaches identified in the works.

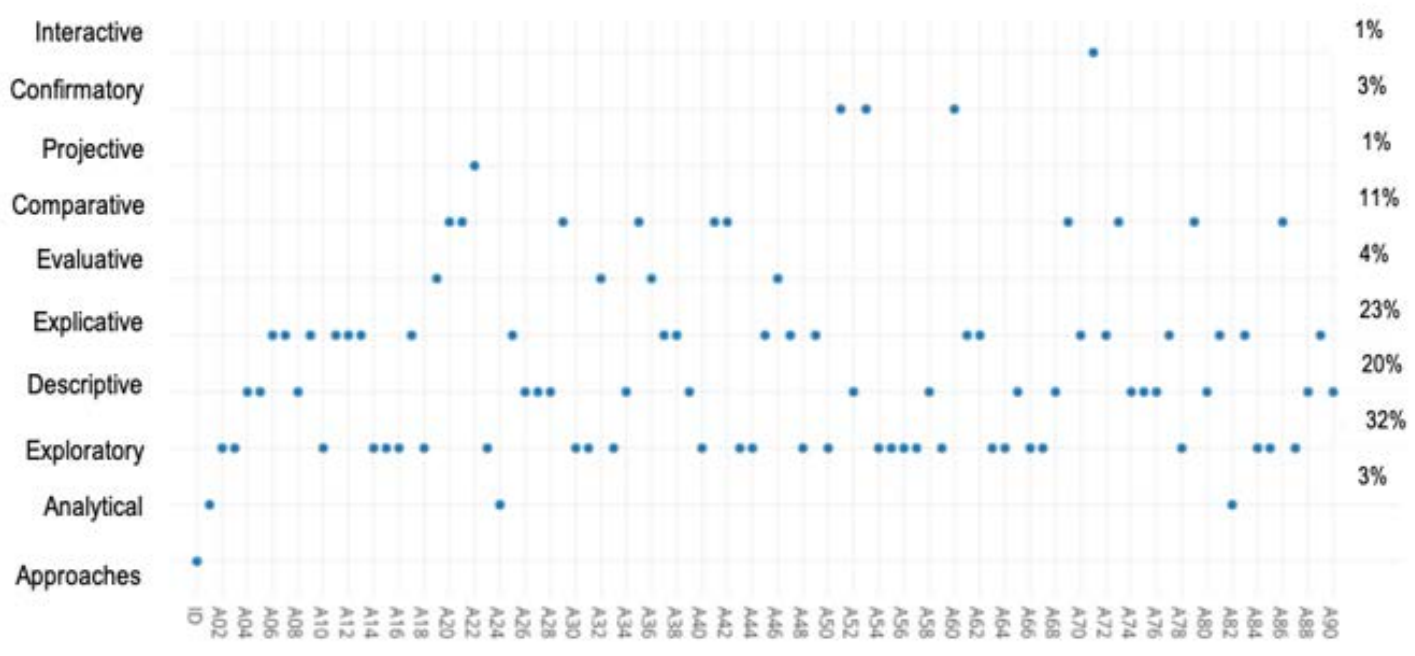

Figure 7. Approaches to educational research used in the documents.

Table 8 presents the sets of documents that belong to each approach and in each research path. 
Table 8

Classification by Approach and Research Method

\begin{tabular}{|c|c|c|c|c|c|}
\hline Approach & $\begin{array}{l}\text { Mixed } \\
\text { methods }\end{array}$ & $\begin{array}{l}\text { Quantitative } \\
\text { research }\end{array}$ & $\begin{array}{l}\text { Qualitative } \\
\text { research }\end{array}$ & Total & ID \\
\hline Exploratory & $2 \%$ & $6 \%$ & $24 \%$ & $32 \%$ & $\begin{array}{l}\text { A02, A03, A10, A13, A14, } \\
\text { A15, A16, A18, A23, A30, } \\
\text { A31, A33, A40, A43, A44, } \\
\text { A48, A50, A54, A55, A56, } \\
\text { A57, A59, A63, A64, A66, } \\
\text { A78, A84, A85, A87 }\end{array}$ \\
\hline Explanatory & $3 \%$ & $20 \%$ & & $23 \%$ & $\begin{array}{l}\text { A06, A07, A09, A11, A12, } \\
\text { A17, A25, A37, A38, A45, } \\
\text { A47, A49, A61, A62, A67, } \\
\text { A70, A72, A77, A81, A83, } \\
\text { A89 }\end{array}$ \\
\hline Descriptive & & & $20 \%$ & $20 \%$ & $\begin{array}{l}\text { A04, A05, A08, A26, } \\
\text { A27, A28, A34, A39, A52, } \\
\text { A58, A65, A68, A74, A75, } \\
\text { A76, A80, A88, A90 }\end{array}$ \\
\hline Comparative & $2 \%$ & $8 \%$ & $1 \%$ & $11 \%$ & $\begin{array}{l}\text { A20, A21, A29, A35, A41, } \\
\text { A42, A69, A73, A79, A86 }\end{array}$ \\
\hline Evaluative & & $1 \%$ & $3 \%$ & $4 \%$ & A19, A32, A36, A46 \\
\hline Analytic & $2 \%$ & $1 \%$ & & $3 \%$ & A01, A24, A82 \\
\hline Confirmatory & & $3 \%$ & & $3 \%$ & A51, A53, A60 \\
\hline Interactive & & & $1 \%$ & $1 \%$ & A71 \\
\hline Projective & & & $1 \%$ & $1 \%$ & A22 \\
\hline
\end{tabular}

\section{What Type of Instruments Are Most Used in the Study of Academic Engagement in MOOCs Participants?}

To answer this research question, the method section of the documents found in full text (36) was read, and 4 documents that explicitly mentioned the data collection instruments in the abstract were added. In total, the instrumentation used in 40 documents is reported in this section.

Learning analytics, questionnaires, interviews, and surveys were the most commonly used instruments (see Table 9). It is also worth noting that social networks (Facebook and Twitter) and new technologies in education such as eye-tracking were also used to measure the construct of academic engagement. 
Table 9

Instruments Used

\begin{tabular}{ll}
\hline \multicolumn{1}{c}{ Instruments } & \multicolumn{1}{c}{ ID } \\
\hline Learning analytics & A03, A07, A09, A11, A17, A25, A38, A44, A54, A60, A61, A67, A70, \\
Questionnaires & A02, A53, A54, A55, A62, A66, A77, A44, A60, A63, A76, A79 \\
Interviews & A26, A27, A32, A39, A63, A65, A02, A03, A53, A55 \\
Surveys & A16, A20, A24, A25, A29, A31, A33, A41 \\
Discussion boards & A45, A55, A57 \\
Twitter & A12, A13, A37 \\
Participant Observation & A24, A37 \\
Exams & A06, A45 \\
Facebook & A13, A37 \\
Eye-tracking & A89 \\
\hline Note. More than 40 instruments were found since each document used between one and three instruments.
\end{tabular}

Note. More than 40 instruments were found since each document used between one and three instruments.

\section{What Thematic Lines Emerge in the Study of Academic Engagement in MOOCs Participants?}

From this analysis trends or thematic lines emerged, among which the following stand out: (1) research in the area of course design, instructional design, or improvement of the learning environment (e.g., A04 and A05); (2) research to identify, predict, or know patterns of participation (e.g., A11 and A12); (3) presentation, description of success stories, or evaluation of new pedagogies (e.g., A32 and A35); (4) inquiry into the participant-teacher, participant-participant, or participant-content interaction (e.g., A08 and A26); (5) motivation to learn (e.g., A2 and A31); and (6) persistence (e.g., A25, A37).

Some of theless frequent thematic lines in the MOOCs construct research were: eye-tracking, perseverance, multitasking, gender, evaluation, curriculum design, credits, coaching, and access to Higher Education. The categorization of documents by thematic line type can be found in Table 10. 
Table 10

Research Trends in the Study of Academic Engagement in MOOCs

\begin{tabular}{|c|c|c|}
\hline Trend & Frequency & ID \\
\hline Instructional design & 13 & $\begin{array}{l}\text { A04, A05, A10, A21, A23, A24, A34, A69, A75, A76, A78, } \\
\text { A84, A85 }\end{array}$ \\
\hline Participation patterns & 12 & $\begin{array}{l}\text { A11, A12, A13, A14, A15, A22, A27, A61, A70, A72, A82, } \\
\text { A86 }\end{array}$ \\
\hline New pedagogies & 8 & A32, A35, A36, A41, A42, A46, A68, A71 \\
\hline Interaction & 7 & A08, A26, A33, A47, A57, A59, A66 \\
\hline Learning motivation & 6 & $\mathrm{~A} 02, \mathrm{~A} 31, \mathrm{~A} 44, \mathrm{~A} 48, \mathrm{~A} 58, \mathrm{~A} 63$ \\
\hline Persistence & 6 & $\mathrm{~A} 25, \mathrm{~A} 37, \mathrm{~A} 38, \mathrm{~A} 45, \mathrm{~A} 49 \mathrm{~A} 60$ \\
\hline Learning communities & 5 & $\mathrm{~A} 20, \mathrm{~A} 43, \mathrm{~A} 50, \mathrm{~A} 52, \mathrm{~A} 77$ \\
\hline Academic performance & 5 & $\mathrm{~A} 07, \mathrm{~A} 09, \mathrm{~A} 54, \mathrm{~A} 67, \mathrm{~A} 79$ \\
\hline Theoretical models & 4 & $\mathrm{~A} 01, \mathrm{~A} 40, \mathrm{~A} 74, \mathrm{~A} 90$ \\
\hline Experiences & 3 & A39, A56, A65 \\
\hline Gamification & 3 & A16, A83, A88 \\
\hline Learning analytics & 2 & A30, A73 \\
\hline Self-regulated learning & 2 & $\mathrm{~A} 62, \mathrm{~A} 64$ \\
\hline Production of digital media & 2 & A18, A87 \\
\hline Feedback & 2 & $\mathrm{~A} 03, \mathrm{~A} 06$ \\
\hline Access to Higher Education & 1 & A55 \\
\hline Coaching & 1 & A80 \\
\hline Credits & 1 & A29 \\
\hline Dropout & 1 & A28 \\
\hline curriculum design & 1 & A18 \\
\hline Evaluation & 1 & A51 \\
\hline Gender & 1 & A17 \\
\hline Multitasking & 1 & A53 \\
\hline Perseverance & 1 & A81 \\
\hline Eye-tracking & 1 & A89 \\
\hline
\end{tabular}




\section{Conclusions}

Although in a SMS the decisions about the search nucleus and the limits are chosen by the authors, an arbitrary choice, the mappings are at the upper end of the spectrum of reliability in an investigation to gain a vision of the state of the art of a research topic (Cooper, 2016; Perryman, 2016). Theresults of this research provide useful information about the state of the art of research on the construct of academic engagement in massive and open online environments.

The results confirm that the production of the construct is increasing and, as in the research of Raffaghelli et al. (2015) and Veletsianos and Shepherdson (2016), in the study of academic engagement this same trend is forecast for 2018. Until now, research on the construct is reported more frequently in journals than in conference proceedings/ or reading books. The main journals in which it is published are in the quartile 1 (Q1) with the highest position and highest impact factor according to the J ournal Citation Report, with hindexes greater than 24 . This speaks not only of the current impact of the issue but also of the quality in which the results are being disseminated.

This research also sheds light on which documents have the greatest incidence in the area, in addition to providing information about the authors and documents with the highest number of citations. The three categories in which the most referenced documents are grouped are: (1) instructional design, (2) how to achieve learning, and (3) motivation and persistence. This tells us that research in this area is only recently emerging, a finding consistent with the research of J oksimovic et al. (2018). This can also be reflected in the documents identified in this research study with the highest number of citations (see Table 6). In these documents, and according to J oksimovic et al. (2018), researchers and professors interested in online education are searching for a framework for the academic engagement construct, one that may provide infrastructure as well as allow for comparison and contrast of the different dimensions of the engagement and pedagogical practices in MOOCs, and thus lead to a greater scientific understanding of how learning happens at scale.

Most of the documents selected in this study correspond to qualitative research that seeks to describe a phenomenon to understand it in depth. This result could be due to the fact that the theoretical and conceptual frameworks for online learning environments are still in development (de Barba, et al., 2016; Gašević et al., 2015; Greene et al., 2015). However, following the methodological design classification scheme of Creswell $(2007,2012)$ and Creswell and Poth (2018), 31\% of the documents have correlational designs. The objective of predicting the success of students in MOOCs, not only to construct predictive models but also to explain the variance in diverse dependent variables of interest, is a very relevant objective to incorporate interventions for the improvement of these learning environments. The previous results contrast with the research carried out by Veletsianos and Shepherdson (2016) in which they report that research in MOOCs follows a quantitative approach with automated methods; however, the results support the research of Raffaghelli et al. (2015) and Bozkurt et al. (2017) which argue that the majority of MOOCs research consists of conceptual/ descriptive studies. One limitation of this result is that, of the 90 documents selected for this SMS, only 36 were availablein their full-text version. Therefore, it was only possibleto read the method section of 36 out of 90 documents. The reading of only the abstract and title of the rest of the documents, on some occasions, may not have accurately reflected the methodological designs used. 
Learning analytics emerged as the main source of data collection in the area, followed by questionnaires, interviews, surveys, and forums. However, other more easily accessiblemethods of data collection emerged, such as the use of the social networks Twitter and Facebook. Methods that might be considered more technological also emerged, such as eye-tracking. The systematic study of the dimensions and variables used to measure the construct is an interesting topic to study in future research.

Although the SMS was carried out in a short time (2015-2018), the results showed that the research of the academic engagement construct seems to be distributed and have a presence in the five continents, with the largest number of articles published in the United States of America (23\%); this result was expected since the most popular platforms were developed in that country (e.g., Edx, Coursera, Udacity). These statements differ from the research of Veletsianos and Shepherdson (2016) in which they report that 80\% of MOOCs studies were published in North America and Europe. In this case, in the research of academic engagement, only 56\% were published in these two areas, Asia and Oceania participated with 16\% and 20\% respectively. An interesting question for future research would be to investigate which topics are addressed in the different geographical regions.

Some of the research trends that were identified within the study at hand were also identified within previous research. For example, Ebben and Murphy (2014), identified learning analytics as a research trend, and Sa'Don et al. (2014) identified interaction and instructional design. Specifically in the research on the academic engagement construct, the two strongest thematic lines were (1) instructional design and (2) participation patterns, which tells us about the interest of researchers to find empirical evidence about the major challenges of MOOCs with respect to retention (Greene et al., 2015), desertion (Halawa et al., 2014), motivation (Kizilcec \& Schneider, 2015), and a design that enhances all of the above (Conole, 2015). Although less frequent, themes that arose within the research reviewed that could be of interest for future research include the study of perseverance, the production of digital media, policies of access to Higher Education, eye-tracking, the competence of multitasking, and mentoring or coaching. The latter was also identified by Raffaghelli et al. (2015) as a deep area in need of research on ways to improve learning outcomes in these environments.

In summary, the results of this study contribute to the investigation of online, massive and open learning environments in two ways. First, the research that has been carried out on academic engagement in said environments was identified; and, second, it provides the academic community with a better understanding of the opportunities for future research, identifying relevant issues and challenges in the area.

Given that research in these environments is a topic with growing academic activity, this work recognizes the importance of new frames of reference that strengthen the knowledge we have about mass learning. Undoubtedly, the gaps and research challenges in MOOCs cannot be achieved without ambition for a better understanding of the academic engagement construct. 


\section{Acknowledgment}

This research is the product of Project 266632 "Binational Laboratory for the Intelligent Management of Energy Sustainability and Technological Training", funded by the CONACYT SENER Energy Fund. Sustainability (Agreement: S0019-2014-01). 


\section{References}

Anderson, A., Huttenlocher, D., Kleinberg, J ., \& Leskovec, J . (2014). Engaging with massive online courses. In Proceedings of the 23rd International Conference on World Wide Web - WWW '14 (pp. 687-698). Seoul, Korea. doi:10.1145/2566486.2568042

Appleton, J . J ., Christenson, S. L., \& Furlong, M. J . (2008). Student engagement with school: Critical conceptual and methodological issues of the construct. Psychology in the Schools, 45(5), 369-386. doi:10.1002/ pits.20303

Bozkurt, A., Akgün-Özbek, E., \&Zawacki-Richter, O. (2017). Trends and patterns in massive open online courses: Review and content analysis of research on MOOC (2008-2015). The International Review of Research in Open and Distributed Learning, 18(5), 1-19. doi:10.19173/irrodl.v18i5.3080

Breslow, L. B., Pritchard, D. E., DeBoer, J ., Stump, G. S., Ho, A. D., \& Seaton, D. T. (2013). Studying learning in the worldwide classroom: Research into edX's first MOOC. Research \& Practice in Assessment, 8 13-25. Retrieved from https:// www.rpajournal.com/ dev/ wpcontent/ uploads/2013/05/SF2.pdf

Carter, C. P., Reschly, A. L., Lovelace, M. D., Appleton, J .J ., \& Thompson, D. (2012). Measuring student engagement among elementary students: Pilot of the Student Engagement InstrumentElementary Version. School Psychology Quarterly, 27(2), 61-73. doi:10.1037/a0029229

Conole, G. (2015). Designing effective MOOC. Educational Media International, 52(4), 239-252. doi:10.1080/09523987.2015.1125989

Cooper, D. (2016). What is a mapping study? J ournal of the Medical Library Association, 104(1), 76-78. doi:10.3163/ 1536-5050.104.1.013

Creswell, J . W. (2012). Educational research: Planning, conducting, and evaluating quantitative and qualitative research (4th ed.). Boston, MA: Pearson. doi:10.1017/CBO9781107415324.004

Creswell, J . W. (2007). Qualitative inquiry and research design: Choosing among five approaches (Vol. 2). Thousand Oaks, CA: Sage. doi:10.1016/j.aenj.2008.02.005

Creswell, J . W., \& Poth, C. (2018). Qualitative inquiry and research design: Choosing among five approaches. Los Ángeles, CA: Sage.

de Barba, P. G., Kennedy, G. E., \&Ainley, M. D. (2016). The role of students' motivation and participation in predicting performance in a MOOC. J ournal of Computer Assisted Learning, 32(3), 218-231. doi:10.1111/jcal.12130

Dybå, T., Dingsøyr, T., \& Hanssen, G. K. (2007). Applying systematic reviews to diverse study types: An experience report. In Proceedings - 1st International Symposium on Empirical Software 
Engineering and Measurement, ESEM 2007 (pp. 225-234). Madrid, Spain. doi:10.1109/ESEM.2007.21

Ebben, M., \& Murphy, J . S. (2014). Unpacking MOOC scholarly discourse: A review of nascent MOOC scholarship. Learning, Media, and Technology, 39(3), 328-345.

doi:10.1080/17439884.2013.878352

Gašević, D., Dawson, S., \& Siemens, G. (2015). Let's not forget: Learning analytics are about learning. TechTrends, 59(1), 64-71. doi:10.1007/ s11528-014-0822-x

Greene, J . A., Oswald, C. A., \& Pomerantz, J . (2015). Predictors of retention and achievement in a massive open online course. American Educational Research J ournal, 52(5), 925-955. doi:10.3102/ 0002831215584621

Halawa, S., Greene, D., \& Mitchell, J . (2014). Dropout prediction in MOOCs using learner activity features. eLearning Papers, 37, 1-10. Retrieved from https:// pdfs.semanticscholar.org/a6d3/ 082a9a077d8f935bfefba1a4449bf5443f20.pdf? ga=2.265 $\underline{077195.578108738 .1551219502-1104262769.1531256554}$

Hurtado, J . (2010). Guía para la comprensión holística de la ciencia [Guide for the holistic understanding of science]. Dirección de investigación y posgrado (Vol. 2). Caracas, Venezuela.

Joksimovic, S., Poquet, A., Kovanovic, V., Dowell, N., Millis, C., Gasevic, D., \&Brooks, C. (2018). How do we model learning at scale? A systematic review of research on MOOC. Review of Educational Research, 88(1), 43-86. doi: 10.3102/0034654317740335

Jordan, K. (2014). Initial trends in enrolment and completion of massive open online courses. International Review of Research in Open and Distance Learning, 15(1), 133-160. doi:10.19173/irrodl.v15i1.1651

Kitchenham, B., \& Charters, S. (2007). Guidelines for performing systematic literature reviews in software engineering Version 2.3 (Report No. EBSE-2007-01). Keele University and University of Durham.

Kizilcec, R. F., Pérez-Sanagustín, M., \& Maldonado, J . J . (2016). Self-regulated learning strategies predict learner behavior and goal attainment in massive open online courses. Computers and Education, 104, 18-33. doi:10.1016/j.compedu.2016.10.001

Kizilcec, R. F., Piech, C., \& Schneider, E. (2013). Deconstructing disengagement: Analyzing learner subpopulations in massive open online courses. In Lak '13. Leuven, Belgium. doi:10.1145/2460296.2460330

Kizilcec, R. F., \& Schneider, E. (2015). Motivation as a lens to understand online learners. ACM Transactions on Computer-Human Interaction, 22(2), 1-24. doi:10.1145/ 2699735 
Milligan, C., Littlejohn, A., \& Margaryan, A. (2013). Patterns of engagement in connectivist MOOC. MERLOT J ournal of Online Learning and Teaching, 9(2), 149-159. Retrieved from http://jolt.merlot.org/vol9no2/milligan 0613.pdf

Newmann, F., Wehlage, G., \& Lamborn, S. (1992). The significance and sources of student engagement. In F. Newmann (Ed.), Student engagement and achievement in American secondary schools (pp. 1139). NewYork, NY: Teachers College, Columbia University. doi: 10.4236/ ojapps.2014.45022

Perna, L.W., Ruby, A., Boruch, R.F., Wang, N., Scull, J ., Ahmad, S. \& Evans, C. (2014). Moving through MOOCs: Understanding the progression of users in massive open online courses. Educational Researcher, 43(9), 421-432. Retrieved from https:// www.learntechlib.org/p/ 157468/

Perryman, C. L. (2016). Mapping studies. J ournal of the Medical Library Association, 104(1), 79-82. doi:10.3163/ 1536-5050.104.1.014

Petersen, K., Vakkalanka, S., \& Kuzniarz, L. (2015). Guidelines for conducting systematic mapping studies in software engineering: An update. Information and Software Technology, 64, 1-18. doi:10.1016/j.infsof.2015.03.007

Raffaghelli, J ., Cucchiara, S., \& Persico, D. (2015). Methodological approaches in MOOC research: Retracing the myth of Proteus. British J ournal of Educational Technologies, 46(3), 488-509. doi: 10.1111/ bjet. 12279

Reschly, A. L., \&Christenson, S. L. (2012). Jingle, jangle, and conceptual haziness: Evolution and future directions of the engagement construct. In S. L. Christenson, A. L. Reschly, \&C. Wylie (Eds.), Handbook of research on student engagement (pp. 3-20). New York, NY: Springer.

Sa'Don, N. F., Alias, R. A., \& Ohshima, N. (2014). Nascent research trends in MOOC in higher educational institutions: A systematic literature review. In International Conference on Web and Open Access to Learning, ICWOAL 2014. Dubai, United Arab Emirates. doi: 10.1109/ICWOAL.2014.7009215

Valdivia, J . A., Ramírez-Montoya, M. S., \&Valenzuela, J . R. (2018). Motivation and knowledge: Preassessment and post-assessment of MOOC participants from an energy and sustainability project. International Review of Research in Open and Distributed Learning, 19 (4). doi: 10.19173/irrodl.v19i4.3489

Veletsianos, G., \& Shepherdson, P. (2016). A systematic analysis and synthesis of the empirical MOOC literature published in 2013-2015. The International Review of Research in Open and Distributed Learning, 17(2). doi: 10.19173/irrodl.v17i2.2448

York, T. T., Gibson, C., \& Rankin, S. (2015). Defining and measuring academic success. Practical Assessment. Research \& Evaluation, 20(5), 1-20. Retrieved from http:// pareonline.net/ getvn.asp?v $=20 \& n=5$ 
Systematic Mapping Study of Academic Engagement in MOOC Guajardo-Leal, Navarro-Corona, and González

Athabasca

University

(c) 